\title{
The introduction of the glaze in al-Andalus: Technological waves and Oriental influences
}

\author{
By Elena Salinas and Trinitat Pradell
}

\begin{abstract}
This research develops a much-needed approach to the study of glazed ware production in al-Andalus (Muslim Spain and Portugal) during the early Middle Ages. The introduction of glaze to the Iberian Peninsula was a long and complex process involving three waves of technology transfer arriving from the eastern Islamic regions between the ninth and eleventh centuries. In this paper, the main glaze workshops of each technological wave have been characterised in order to understand how the medieval technological transmission took place and how political and economic factors influenced this gradual dissemination.

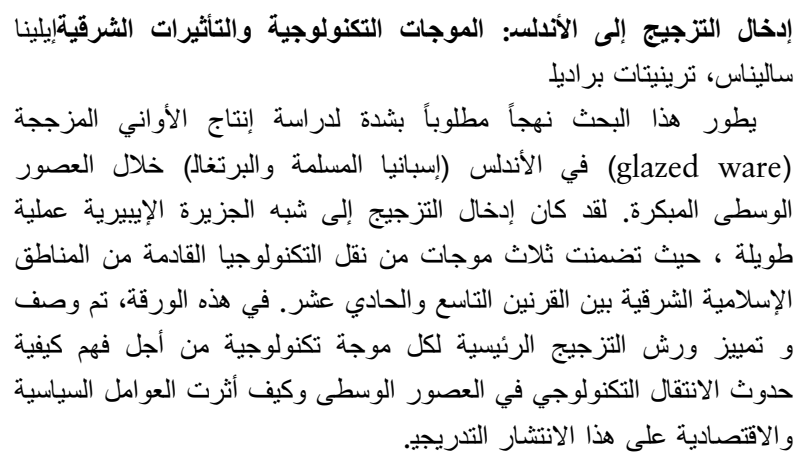

\section{Introduction}

Although the Romans produced lead-glazed ceramics on the Iberian Peninsula, this technology subsequently disappeared. In fact, some vessels from late antiquity contexts that were formerly identified as 'glazed ceramics' have recently been recognised as crucibles for glass production (Peña et al. in press). Glaze technology was reintroduced to Iberia from the Islamic world in several technological waves. This technological transfer did not reach the Peninsula - which was conquered by the Arabs and Berbers in $711 \mathrm{CE}$ - in the early days of al-Andalus, in spite of the spread of glaze technology throughout the eastern Islamic lands (Syria, Egypt, Iraq, etc.). The first evidence of glazed ware production has to be

\footnotetext{
FThe original version of this article was published with the incorrect abstract. A notice detailing this has been published and the error rectified in the online PDF and HTML copies.

Characterisation of Materials Group (GCM), Physics Department, Universitat Politècnica de Catalunya (UPC-BarcelonaTech), Av. Eduard Maristany 16, Barcelona 08019, Spain
}

dated to the second half of the ninth century in Pechina (Castillo and Martínez 1993).

We began with the initial hypothesis that the main early production and exporting centre of transparent glazed ceramics was located in Pechina (Salinas and Zozaya 2016). There is also archaeological evidence of a later glaze workshop in Málaga (Íñiguez and Mayorga, 1993). No more evidence of early glaze production centres has been found, other than that of Córdoba, which was identified during the course of this investigation. It has been proposed that there was a single polychrome tin-glaze workshop, part of a centralised monopoly (Rosselló 1995), during the Caliphate of Córdoba (929-1031 CE). The fitna or civil war (1009-31 CE) led to the collapse of the caliphate and the fragmentation of power into several 'Taifa' kingdoms (1031-85 CE). One of the consequences of this was that tin-glaze technology spread to the new capitals of the kingdoms, coinciding with the beginning of lustre production.

Unlike in the eastern Islamic regions, the transmission of glaze technology know-how in al-Andalus did not take place all at once. In fact, it needed over two centuries of assimilation and was heavily conditioned by political and economic events. Three technological glaze waves can be identified: the first in the mid ninth century with the production of transparent glazes; the second in the early tenth century, comprising the production of opaque tin glazes; and the third in the mid eleventh century, involving the production of lustredecorated wares (see Table 1).

With regard to the first wave, we focused on southern Iberia (Fig. 1), sampling 16 of the 30 previously identified glaze finds from the emirate of Córdoba (Salinas and Zozaya 2016). We followed a quantification criteria, as most of the northern sites only contained one or two glazed samples, whereas the studied settlements had more - between three and 1,500 (the latter from a workshop area). They made up the bulk of this study, with a total of 152 early glazed samples analysed. In order to understand the transition to the second wave, 40 samples from four sites were selected for study. Finally, the third wave was addressed by analysing three pieces of evidence from the only possible lustre workshop identified so far. There may have been another production centre in north-eastern Iberia (Ortega et al. 2013), 
Table 1 -Summary of historical context and glaze technological waves studied.

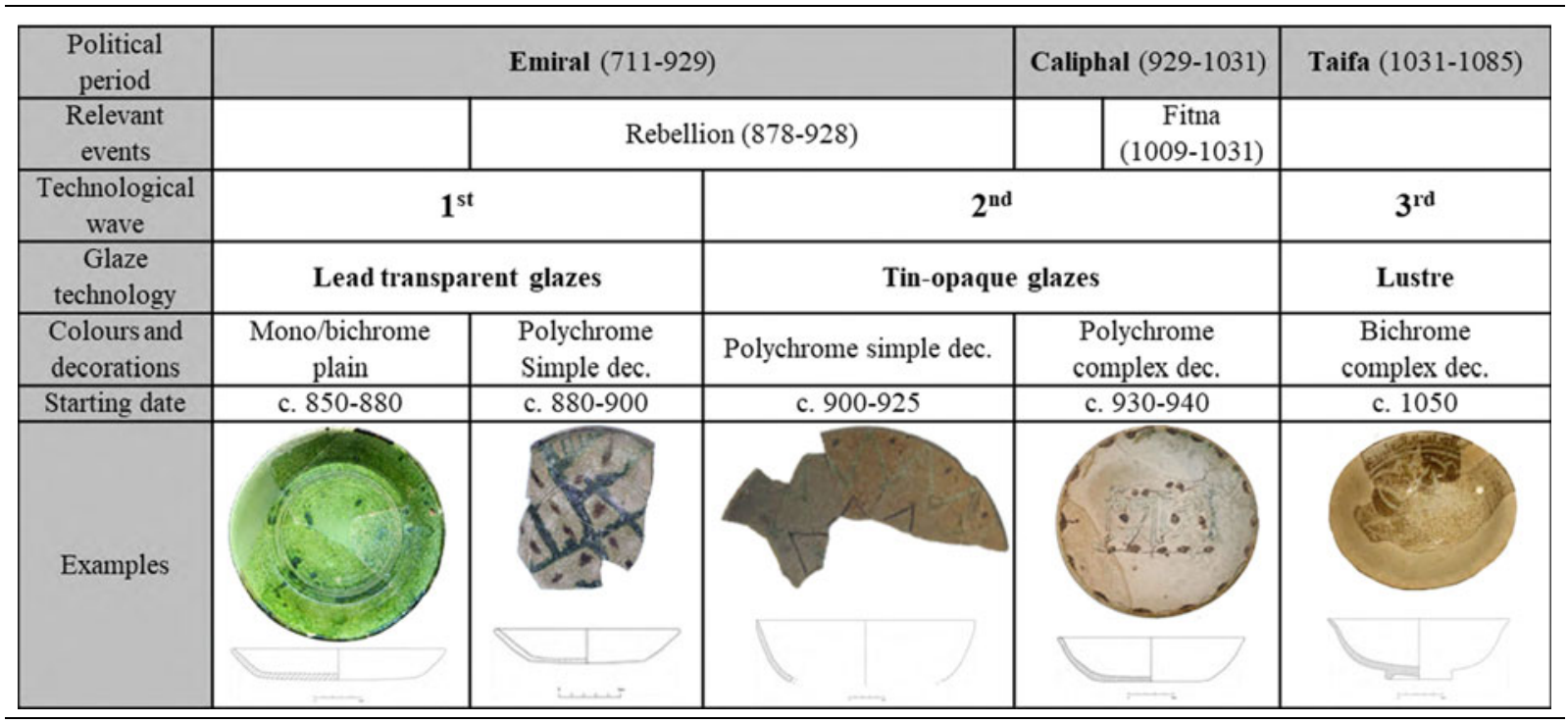

but no archaeological evidence for it has yet been found. In addition, six glazed imports were analysed in order to determine their possible influence on the local productions.

Our approach was multidisciplinary and included historical documentation, archaeological evidence, the sampling of glazed ceramics from well-contextualised archaeological excavations, and chemical and petrographic analyses of ceramic bodies and glazes.

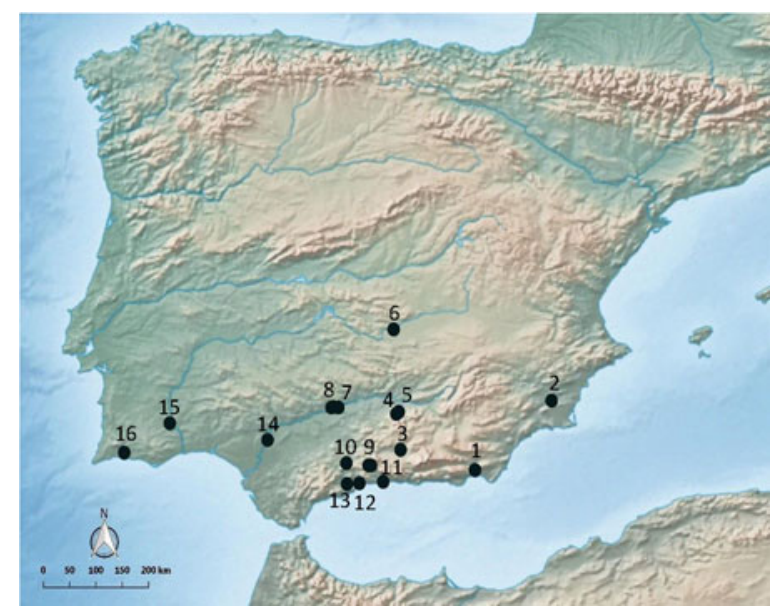

Figure 1. Localisation of the archaeological sites sampled. (1) Pechina. (2) Murcia. (3) Madinat Ilbira. (4) Marroquies Bajos. (5) Puente Tablas. (6) Calatrava la Vieja. (7) Córdoba. (8) Madinat al-Zahra. (9) Alfarnate. (10) Valsequillo. (11) Vélez-Málaga. (12) Bezmiliana. (13) Málaga. (14) Sevilla. (15) Mértola. (16) Silves.

\section{Glaze technologies in medieval Spain}

From the study and analysis of glazed ceramic sherds, we were able to distinguish several glaze and decorative technologies related to the three waves (Table 2). In particular, we distinguished between plain transparent lead glazes, polychrome transparent lead glazes, polychrome opaque tin glazes and lustre designs. The main production centres related to the three technological waves identified so far are shown in Fig. 2.

\section{First glaze technological wave}

After revising archaeological finds from the pottery craft quarters of Málaga, Córdoba and Pechina, their glaze productions have been identified and characterised. These earliest glazed ceramic workshops specialised in glazed tableware and oil lamps with transparent lead glazes, incised decoration, and one or two plain colours applied over each surface. They were in operation during the late ninth and early tenth centuries (Fig. 2).

The composition and technological features of the ceramic pastes and fabric groups were studied to determine their geographical area of origin and to confirm their provenance (Table 2 and Fig. 3). Pechina ware is calcareous $(15-20 \% \mathrm{CaO})$ with fine metamorphic inclusions (mica and schist) and a buff-coloured fabric. Córdoba ware is also calcareous $(10-15 \% \mathrm{CaO})$ with fine sedimentary inclusions (quartz, feldspar, mica and some fossil foraminifera) and coarse round white calcareous and red iron-rich inclusions; the predominant colour is orange. 
Table 2 - Table with the different glaze and decorative technologies used in al-Andalus.

\begin{tabular}{|c|c|c|c|c|c|c|c|c|c|c|c|}
\hline TW & Technique & Chronology & Workshop & Location & Inclusions & Decoration & Patterns & Colour & Colorants & Opacifiers & Firing/s \\
\hline \multirow[t]{4}{*}{1} & $\begin{array}{l}\text { Mono/ } \\
\text { Bichrome } \\
\text { lead } \\
\text { transparent }\end{array}$ & $\begin{array}{l}\text { Second half } \\
\text { of } 9^{\text {th }} \mathrm{C} \text {. }\end{array}$ & V & Pechina & $\begin{array}{l}\text { Metamorphic } \\
\text { mica, schist }\end{array}$ & Plain Incised & & $\begin{array}{l}\text { Green } \\
\text { Amber } \\
\text { Transparent }\end{array}$ & $\mathrm{Cu}, \mathrm{Fe}$ & & 2 \\
\hline & & $\begin{array}{l}\text { Second half } \\
\text { of } 9 \text { th } C \text {. }\end{array}$ & V & Córdoba & $\begin{array}{l}\text { Sedimentary } \\
\text { quartz, feldspar, } \\
\text { calcareous \& } \\
\text { iron-rich inc. }\end{array}$ & $\begin{array}{l}\text { Plain incised } \\
\text { plastic }\end{array}$ & & $\begin{array}{l}\text { Green } \\
\text { Amber }\end{array}$ & $\mathrm{Cu}, \mathrm{Fe}$ & & 2 \\
\hline & & 10th C. & V & Málaga & $\begin{array}{l}\text { Sedimentary } \\
\text { flint, phyllite, } \\
\text { quartz, shells }\end{array}$ & Plain incised & & $\begin{array}{l}\text { Brown } \\
\text { Amber }\end{array}$ & $\mathrm{Mn}, \mathrm{Fe}$ & & $1 ?$ \\
\hline & $\begin{array}{l}\text { Polychrome } \\
\text { lead } \\
\text { transparent }\end{array}$ & $\begin{array}{l}\text { Late } \\
\text { 9th-early } \\
\text { 10th C. }\end{array}$ & & $\begin{array}{l}\text { Córdoba? } \\
\text { Pechina? }\end{array}$ & $\begin{array}{l}\text { Sedimentary } \\
\text { fine quartz \& } \\
\text { mica }\end{array}$ & Overglaze & $\begin{array}{l}\text { Splashes } \\
\text { Geometric }\end{array}$ & $\begin{array}{l}\text { Green } \\
\text { Amber } \\
\text { Brown } \\
\text { Transparent }\end{array}$ & $\mathrm{Cu}, \mathrm{Fe}, \mathrm{Mn}$ & & 2 \\
\hline \multirow[t]{2}{*}{2} & $\begin{array}{l}\text { Polychrome } \\
\text { tin-opaque }\end{array}$ & $\begin{array}{l}\text { Late } \\
\text { 9th-early } 10^{\text {th }} \\
\text { C (Emiral) }\end{array}$ & & Córdoba? & $\begin{array}{l}\text { Sedimentary } \\
\text { fine quartz, } \\
\text { feldspar \& mica }\end{array}$ & Overglaze & Geometric & $\begin{array}{l}\text { Green } \\
\text { Amber } \\
\text { Brown } \\
\text { White }\end{array}$ & $\mathrm{Cu}, \mathrm{Fe}, \mathrm{Mn}$ & $\mathrm{SnO}_{2}$ & 2 \\
\hline & & $\begin{array}{l}\text { 929-1010 } \\
\text { (Caliphal) }\end{array}$ & V & Córdoba & $\begin{array}{l}\text { Sedimentary } \\
\text { quartz, feldspar, } \\
\text { mica, } \\
\text { calcareous inc. }\end{array}$ & Overglaze & $\begin{array}{l}\text { Geometric, } \\
\text { Plant, Zoo, } \\
\text { Epigraphic, } \\
\text { Human }\end{array}$ & $\begin{array}{l}\text { Green } \\
\text { Amber } \\
\text { Brown } \\
\text { White }\end{array}$ & $\mathrm{Cu}, \mathrm{Fe}, \mathrm{Mn}$ & $\mathrm{SnO}_{2}$ & 2 \\
\hline 3 & $\begin{array}{l}\text { Lustre } \\
\text { tin-opaque }\end{array}$ & $\begin{array}{l}\text { Second half } \\
\text { of } 11^{\text {th }} \mathrm{C} \text {. }\end{array}$ & $\mathrm{V} ?$ & Sevilla & $\begin{array}{l}\text { Sedimentary } \\
\text { fine and scarce }\end{array}$ & $\begin{array}{l}\text { Lustre } \\
\text { technology }\end{array}$ & $\begin{array}{l}\text { Geometric } \\
\text { Epigraphic }\end{array}$ & Gold White & $\mathrm{Cu}, \mathrm{Ag}$ & $\mathrm{SnO}_{2}$ & 3 \\
\hline
\end{tabular}




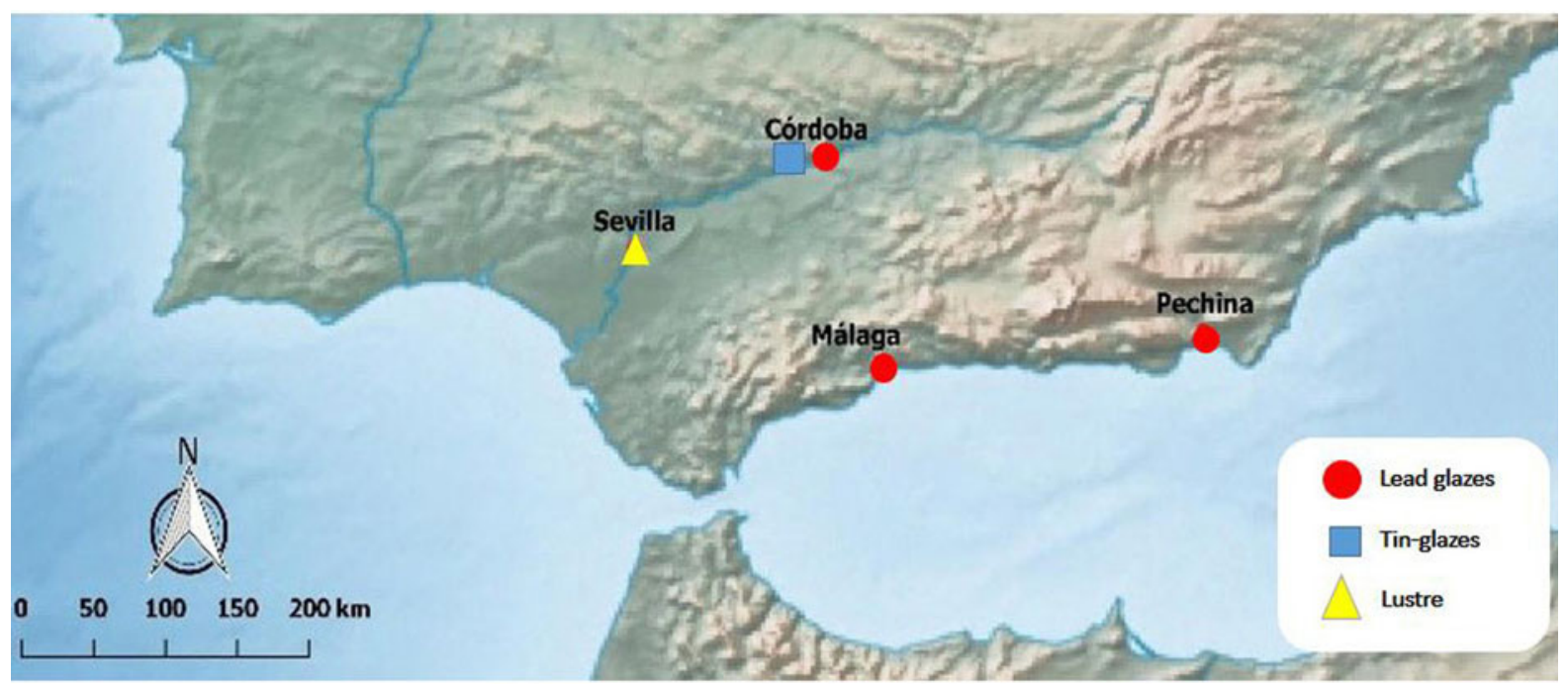

Figure 2. The glaze production centres from al-Andalus corresponding to the three technological waves studied.

Málaga ware has a low calcareous content (5.5-8.5\% $\mathrm{CaO}$ ) with fine sedimentary inclusions (flint, phyllite, quartz and seashells) and an overall red colour with white areas around the reacted seashells, which also provide a porous fabric.

With regard to the glazes, in addition to specific decorative patterns and shapes, each production centre had distinctive technical features in terms of the colorants used and the glaze composition (Table 2 and Fig. 4). Pechina glazes are characterised by a high lead content $(\sim 60 \% \mathrm{PbO})$ and the use of two plain colour glazes, green and amber, obtained by adding copper and iron oxides respectively. Málaga glazes have a lower lead content $(\sim 40 \% \mathrm{PbO})$ and the main colour is a chocolate brown obtained by the combined addition of manganese and iron oxides. In contrast, the most representative Córdoba glazes are amber (with added iron oxide) and, to a lesser extent, green (with added copper oxide), and intermediate lead content $(\sim 50 \% \mathrm{PbO})$.

Although they initially produced glazed ware with different colours on each side, they later incorporated polychromies (Tables 1 and 2), although with some nuances. In fact, the earliest Pechina workshop presumably moved to a nearby area, probably in the late ninth century, before this technical change was introduced. Archaeological excavations have revealed evidence of polychrome glazed ceramics production in its activity area related to the new Pechina workshop during the tenth century (Castillo and Martínez 1993). The Málaga workshop began operating in the early tenth century and, over the years, added brown brush strokes over the amber glaze background, but no other coloured decoration. Each workshop had its own characteristics: techniques, colorants, raw materials, composition and style, vessel shapes and the application of the decorations. All these elements created a distinctive glaze tradition in al-Andalus, different to those from other Islamic regions. Regarding the spread and distribution of the different glazed ware production throughout the Iberian Peninsula, it has been assessed that the three glazed ware productions have been found outside their local markets.

In the case of Córdoba, an early transparent polychrome production of very short duration (green and brown glazes over a transparent glaze) has been identified at the turn of the tenth century (Salinas and Pradell 2018). This production was rapidly replaced in the early tenth century by the polychrome tinglazed ware related to the second technological wave. However, polychrome transparent lead-glazed ware reappeared in Córdoba during the late tenth and early eleventh centuries, replacing the white background opaque tin glaze with a transparent amber glaze. This could be related to the shortage of tin at the end of the Caliphate and during the civil war, as the tin sources located in western Iberia and Córdoba had lost control of those territories.

\section{Second glaze technological wave}

The first al-Andalus tin-glaze production specialised in polychrome ware with simple green (copper) and brown (manganese) designs applied on one of the sides over a white opaque glaze background achieved by the addition of cassiterite cassiterite $\left(\mathrm{SnO}_{2}\right)$ (Table 1, Fig. 5). The undecorated side was also covered by a plain white tin glaze (Fig. 5). This production has been identified in the Emirate 

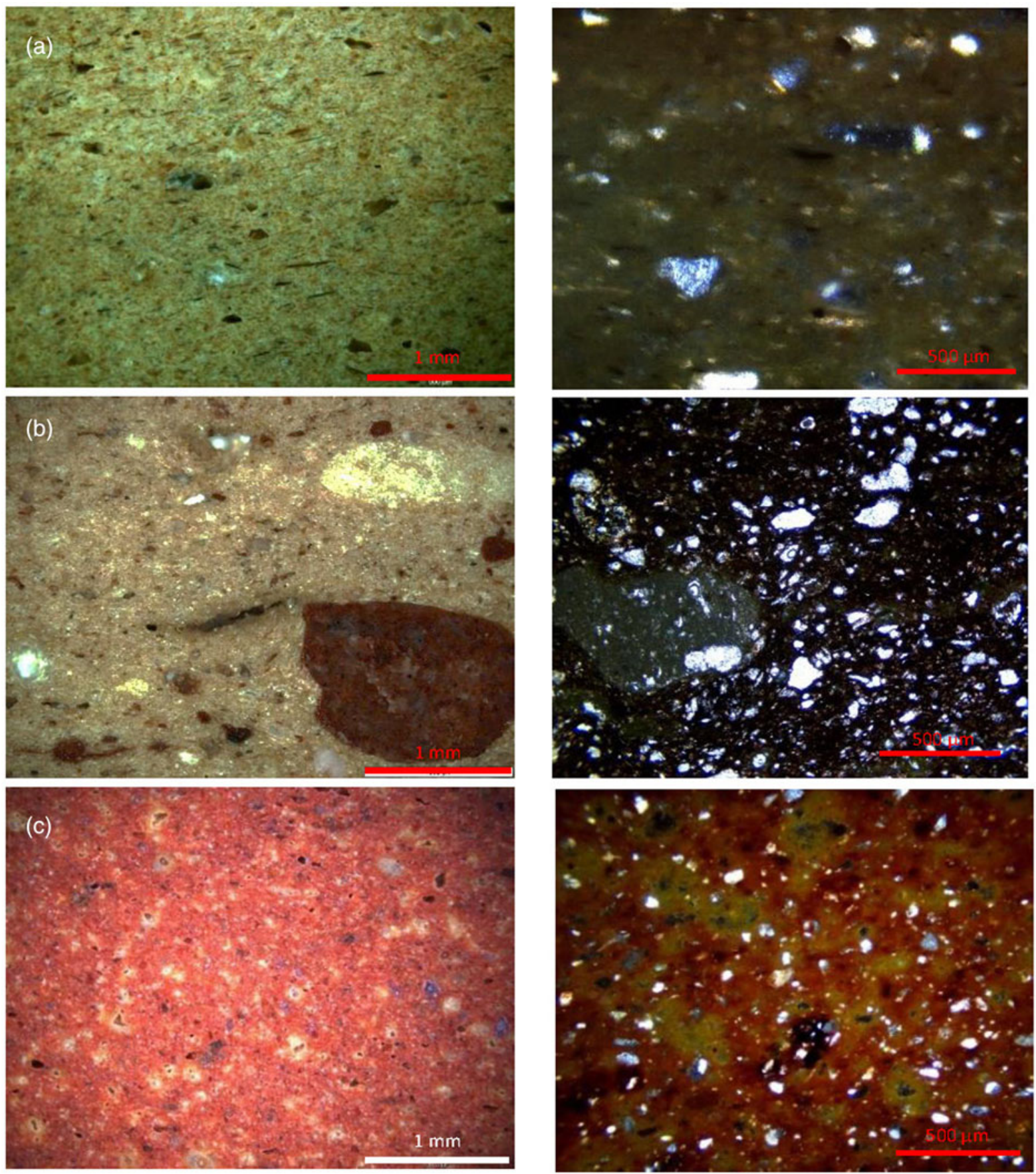

Figure 3. (Left) optical microscopy and (right) petrographic microscopy images of the ceramic fabrics from the three workshops from the first technological wave: (a) Pechina; (b) Córdoba; (c) Málaga.

in Córdoba (late ninth-early tenth century) and is a continuation of the earlier polychrome transparent lead-glaze production in terms of its application method and designs - the overglaze painting of simple patterns. The analyses carried out have revealed a connection with the Abbasid world, probably Mesopotamia (present-day Iraq) (Matin et al. 2018) rather than North Africa. This is a significant outcome, as both lead- and tin-glaze technologies have traditionally been linked to the Aghlabids (medieval Ifriqiya, present-day Tunisia) (Rosselló 1995).
Later, polychrome tin-glazed ware continued to be produced under the Caliphate (929-1031 CE), by that time with more complex design patterns than in the Emirate. Moreover, the undecorated side was covered by a transparent lead glaze, often amber-coloured, instead of a plain tin glaze. Subsequently, in the eleventh century, tin-glaze technology spread across al-Andalus and other peripheral production centres located in the seats of the Taifa kingdoms emerged.

It should be highlighted that the existence of an early tin-glaze production in al-Andalus has long 


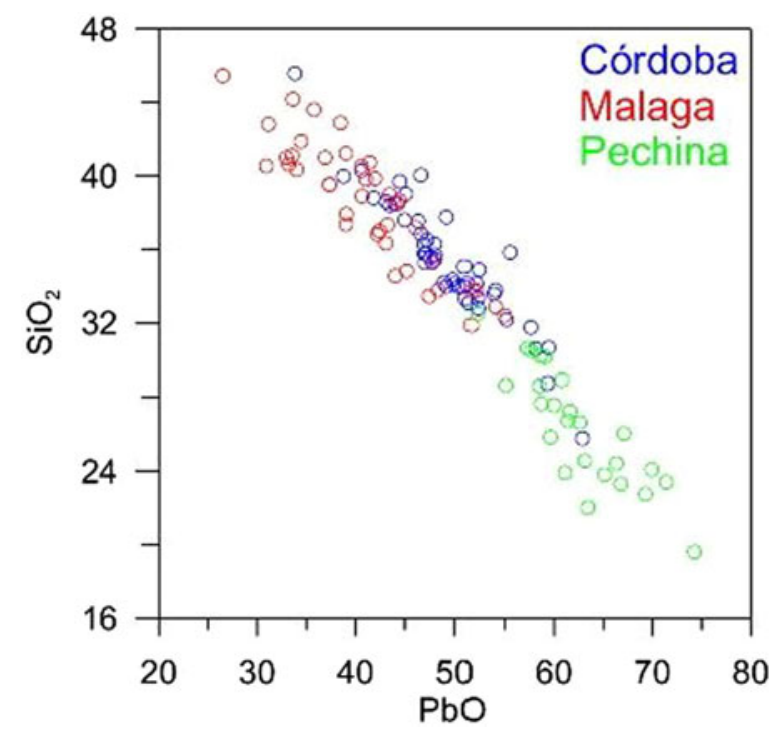

Figure 4. SiO2 versus $\mathrm{PbO}$ composition of the glazes corresponding to the three workshops from the first technological wave. been questioned due to the poor preservation of the glazes, leading it to be confused with slips (Escudero 1991, 135). The glazes usually presented a low vitrified surface, muted brilliance and a dusty appearance. Analyses have demonstrated that this appearance is due to the alteration of the glazes, the precipitation of lead carbonates and also phosphates (see Fig. 5), together with the tin oxide particles. The reasons for this lack of adequate preservation of the glazes could be linked to the procedure followed in the tin-glaze production or to the acidic nature of the soil in an urban environment.

\section{Third glaze technological wave}

Lustre was the most complex decorative technique and the last technological wave to reach al-Andalus (mid eleventh century). It is highly likely that the earliest lustre production centre was in the Alcazar of Seville (the palace of the local ruling dynasty). Two lustre rejects from this earliest production

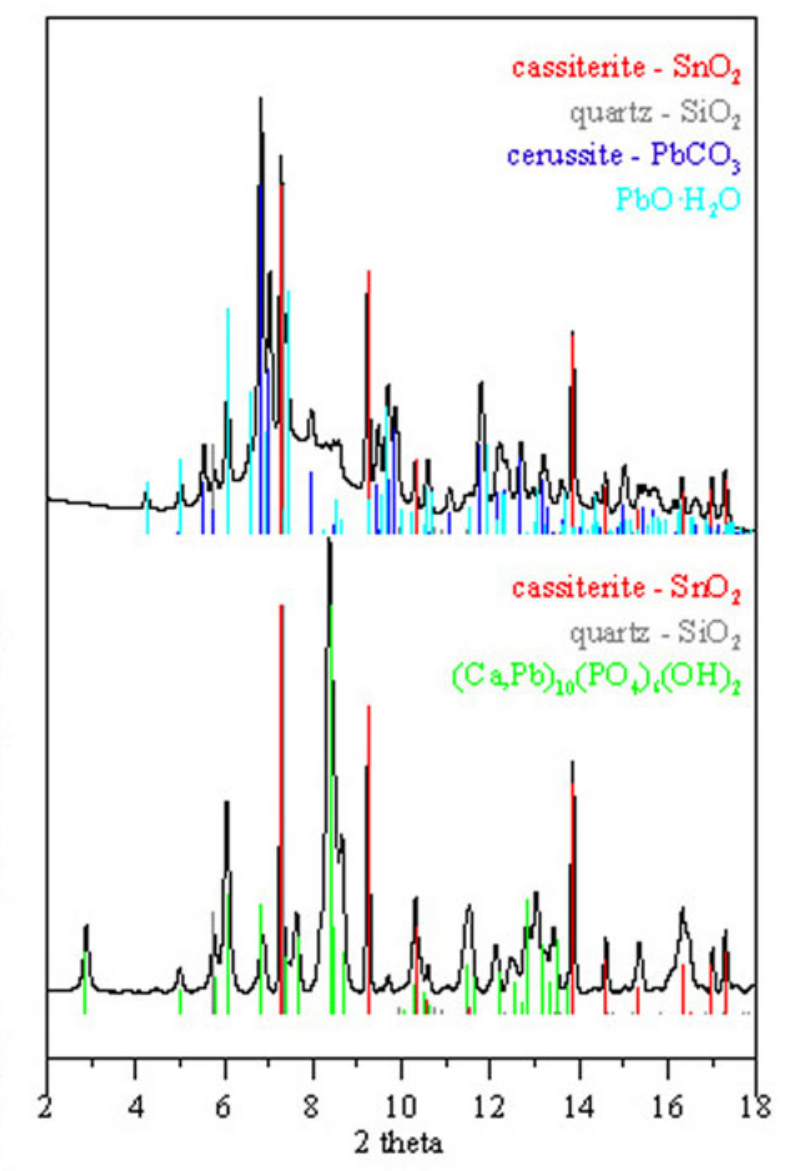

Figure 5. Optical microscopy and scanning electronic microscopy back scattering images and micro-X-ray diffraction analysis of a polychrome opaque glazed ceramic, dated in the Emiral period (late ninth-early tenth century), showing the presence of the dusty appearance of the glaze, the alteration shown which is identified as lead carbonate and lead oxide hydrate. 


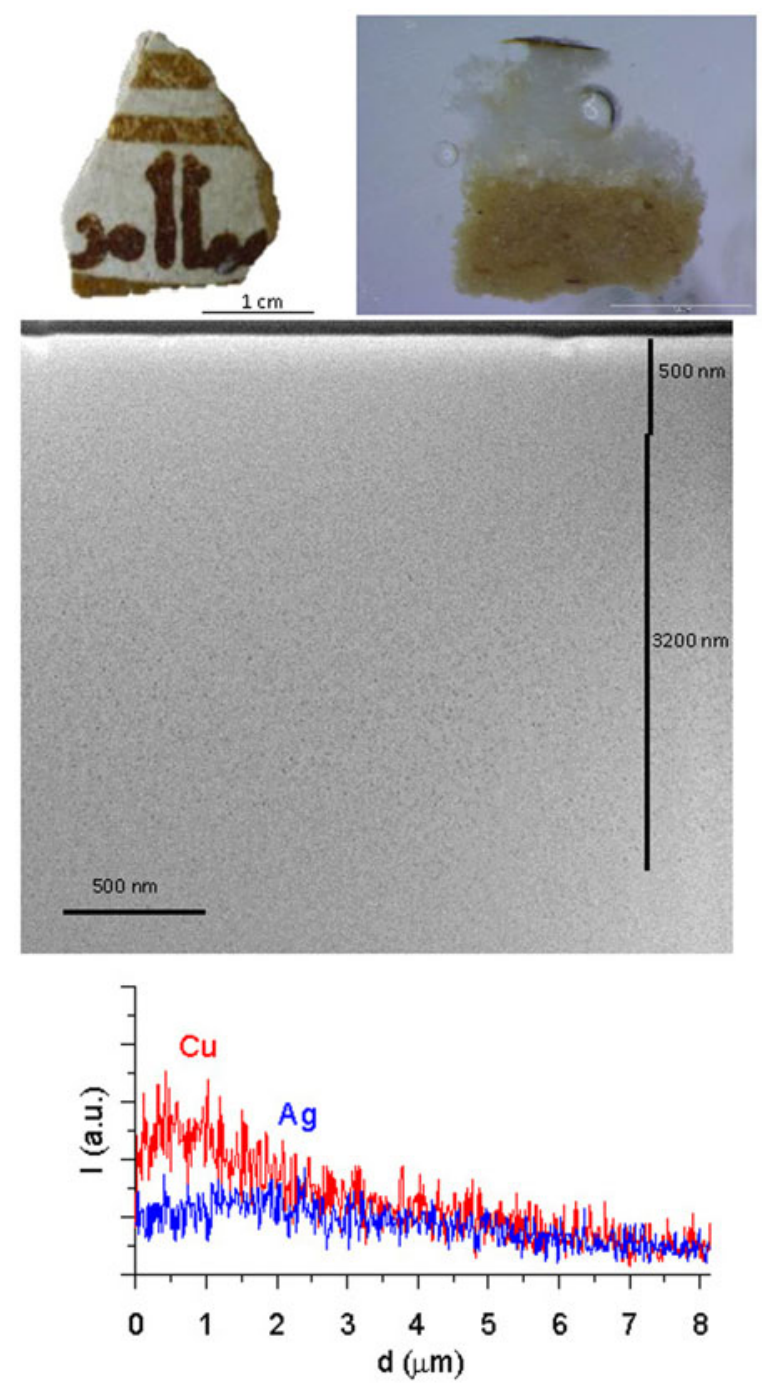

Figure 6. Lustre sample analysed with scanning electronic microscopy with focused ion beam, showing the presence of a surface thin layer of metal silver nanoparticles and distribution of copper and silver in the layer thickness.

were analysed and revealed the characteristic thin silver- and copper-rich layer $(\approx 1 \mu \mathrm{m}$ thick) containing a small amount of silver/copper metal (some tens of nanometres in size) (Fig. 6). The production from Seville can be compared to that from other lustre workshops in the Calatayud/Zaragoza area which have been analysed previously (Ortega et al. 2013). Comparison with contemporary production centres (Egypt, Tunisia and Syria) is also being carried out to ascertain the origin of the potters who brought the technology to al-Andalus.

\section{Imported glazed wares and influences}

A few glazed ceramics were identified as imported glazed ware from different Islamic regions and periods (Fig. 7). A white opaque glazed example from Mesopotamia (Samarra type) (Carvajal 2013) and a polychrome transparent glaze from Ifriqiya were found at Madinat Ilbira (ninth century). The white opaque tin glaze (Fig. 8a) is a characteristic Abbasid Iraqi production, from a period in which plain white tin glazes were not produced in al-Andalus. Moreover, Iraqi white glazes are alkali-lead and contain a large amount of cassiterite particles (Matin et al. 2018), whereas later tin glazes from al-Andalus are lead-alkali and contain fewer tin oxide particles. With regard to the polychrome transparent glazes, the Ifriqiya production began earlier (under Aghlabid rule, 800-909 CE) than the al-Andalus polychrome transparent glazes. The Ifriqiya glaze shows significant technological differences (Fig. 8b). First, it has a thick creamy ceramic surface layer between a red body and the transparent glaze, probably obtained by adding salted water to the ceramic surface before biscuit firing. Moreover, colour decorations were applied on the ceramic surface below the transparent glaze or underglaze, while in al-Andalus they were applied over the glaze. Finally, coloured glazes with a high lead content were manufactured in al-Andalus, while the Tunisian glazes were lead-alkali (Ben Amara et al. 2001).

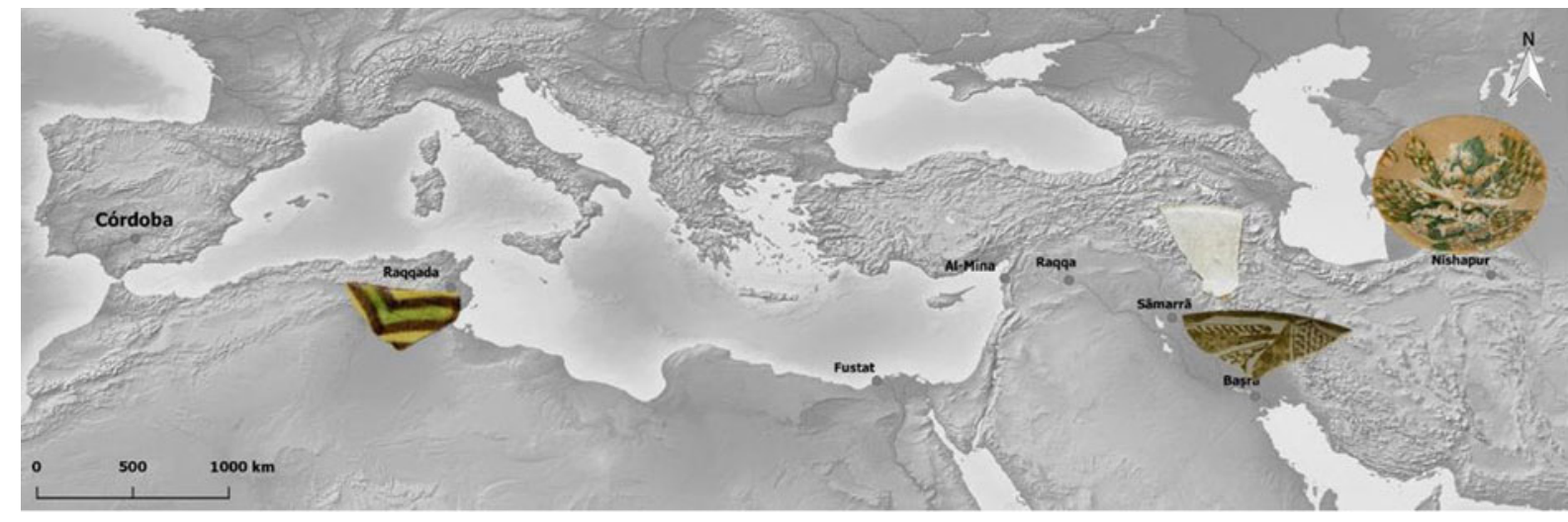

Figure 7. Location of the proposed provenances for the ninth-tenth-century imports found in al-Andalus. 

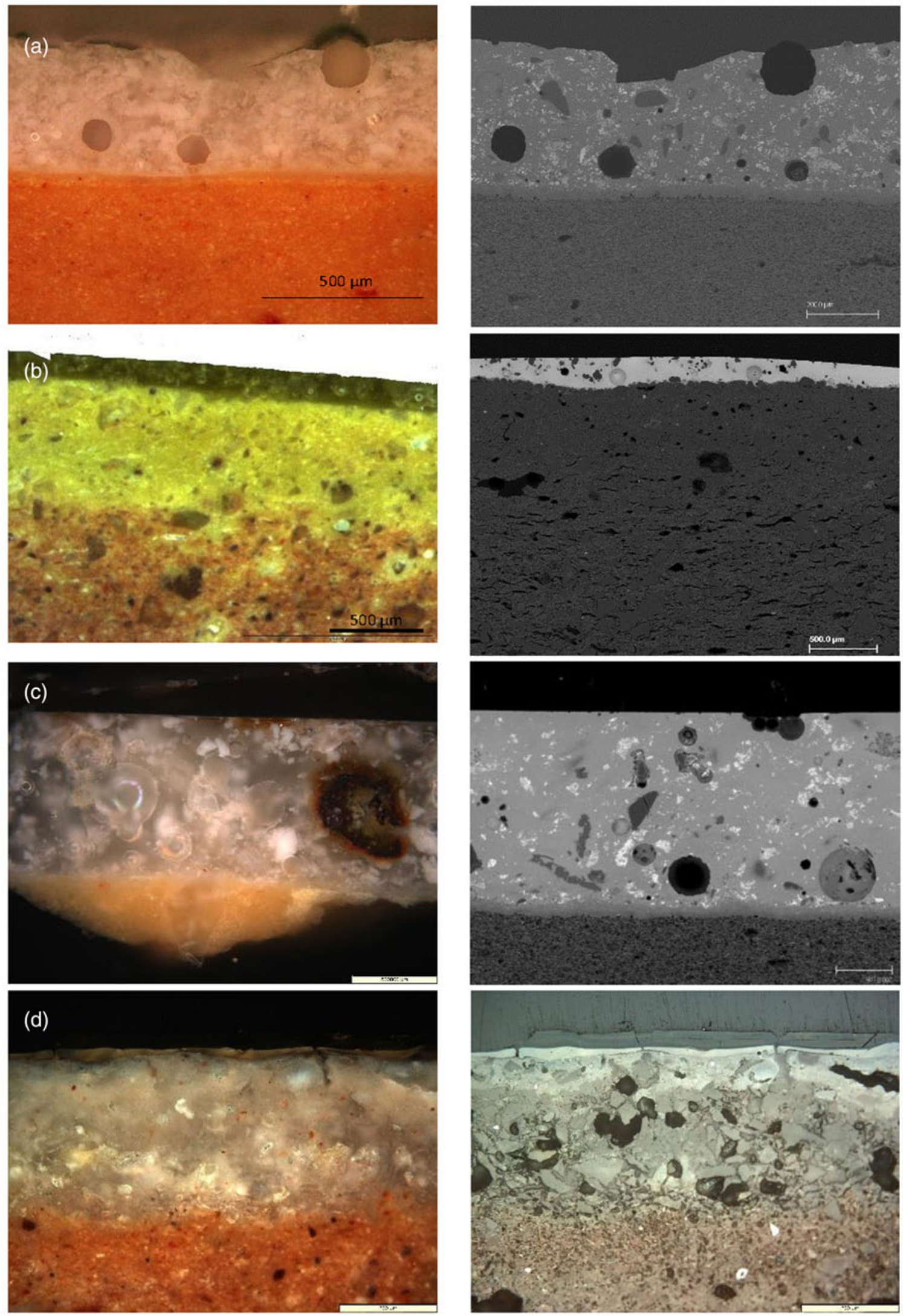

Figure 8. Optical microscopy and scanning electronic microscopy back scattering images of the imported glazed wares: (a) Abbasid white ware, showing a thick homogeneous tin glaze; (b) polychrome glazed ware from Ifriqiya, showing the creamy ceramic surface, underglaze brown decoration and the transparent glaze on top; (c) Abbasid monochrome lustre ware, showing the characteristic thick glaze and microstructure (diopsides, cassiterite particles, bubbles and quartz grains); (d) sgraffitto ware, showing a thin heavily weathered transparent glaze on top of a white slip full of angular quartz grains. 
On the other hand, a set of Abbasid lustre ware and a sgraffito glazed dish from the palace area of Madinnat al-Zahrā' are the most significant imports (second half of the tenth century). No other contemporary lustre or sgraffito examples have been found in al-Andalus to date. The lustre ware was analysed in order to rule out a local provenance. Previous archaeological studies proposed an Egyptian provenance (Heidenreich 2007); however, the chemical composition of the ceramic pastes and glazes links them to the Abbasid lustre ware made in Iraq (Pradell et al. 2008) (Fig. 8c). This means that lustre ware was used in the palace but not produced in al-Andalus in the mid tenth century. It took another century for the lustre technology to reach al-Andalus.

Finally, the sgraffito dish (Fig. 8d) combines a white slip, polychrome splashes and incised decoration under a transparent glaze - a technique that was never used in al-Andalus. In contrast, it was widely produced in Iran and Central Asia during the tenth century (Watson 2004).

\section{Discussion}

Various reasons can be identified for the beginning of local glazed ceramic production and how it relates to each political period, settlement status and relevant events in the history of al-Andalus. The workshops were mainly in large urban locations. Córdoba was the capital of al-Andalus, the political, economic, religious and cultural centre of the Umayyad dynasty from the eighth to the early eleventh centuries. Pechina was the most important port and the gateway for trade with the East in the ninth and tenth centuries. It was enriched by the Mediterranean trade and remained outside the central state rule at a time when Umayyad power was being weakened by continuous rebellions. Málaga emerged as a sea port and was strategically placed to trade with Africa and control the gold route during the tenth century. Finally, Seville was the capital of the Arab Abbadid dynasty and the most powerful kingdom during the eleventh century, gaining control over almost all of southern Spain and Portugal.

With regard to the relationship between the different glaze waves and the cultural, economic, religious and social changes, the first glaze production in al-Andalus by the three identified workshops is linked to both a widespread rebellion against the Emirate of Córdoba (878-929 CE), which led to a period of political instability and weakness, and to a limited spread and use of glazed tableware by a small segment of the al-Andalus population. Political instability and economic crisis (with a halt to monetary issues in Córdoba) may have prevented the spread of the new technology. Archaeological finds show that the early glaze production was not used as an element of political cohesion or religious identity, but as a socioeconomic distinction by an elite who wished to emulate the Abbasid court by adopting oriental trends. Furthermore, following this research, it has been demonstrated that Pechina was not the only workshop with a regional distribution network, as had traditionally been thought; Córdoba and Málaga glaze productions were also sold outside their local markets.

The use of tin for the opaque glazes (second wave) began in the unstable late-Emirate period (before 929 CE) and not during the Caliphate. It appears that this new technology was first used in Córdoba, one of the three earliest glaze craft areas, where a previous market was consolidated. This early polychrome tin-glazed ware presents very simple patterns, far from the complexity and political meaning of the later period. Another possible tinglaze workshop may have operated in the Vega de Granada area (Molera et al. 2018), although no evidence of a workshop has been found so far. The manufacture of this tin-glazed ware continued during the caliphate period, when the glazed ware consumption pattern changed. Transparent lead-glazed ceramics were popularised and subsequently widely used during the tenth and eleventh centuries. This mass consumption led to a simplification of the glaze production process (from an extremely complex process in the ninth-century workshop of Pechina to a more simplified method in the tenth century in Malaga) and the proliferation of workshops specialising in lead-glazed ware (e.g. Murcia, Toledo). Conversely, polychrome tin-glazed ware took over from the earliest transparent lead glazes and their consumption was restricted to a small group of high-status consumers (especially outside of Córdoba where the amount of polychrome tinglazed ware is much lower). Moreover, from the mid tenth century onwards, tin-glazed polychrome ceramics were used as a sign of political and religious power by the Umayyad dynasty. This tendency seems to have continued with the emergence of the lustre technology. Two of the most powerful local dynasties of the Taifa kingdoms emulated the Fatimids, producing their own lustre ware and even decorating it with the king's name as a sign of their power (Table 1).

Considering the evolution of glaze technologies in Iberia during those two centuries in relation to the establishment of new workshops and the distribution of glazed tableware, an obvious concentration of glazed wares is found close to the identified 
production centres (Fig. 1). However, it is not the only explanation for the slow spread of glaze technology to the far west of Iberia (present-day Portugal) (Gómez et al, in press), just as happened in the northern territories (including the Christian Spain). Several factors appear to have been involved - on the one hand, a later Islamisation and orientalisation of both the population and their dining habits, since the use of sophisticated ceramic tableware died out in Iberia during the Late Antiquity. On the other, it may have been due to the lack of a production structure and an organised trade network capable of supplying the entire al-Andalus market. Political or religious do not appear to have been determining factors; the use of glazed tableware was a symbol of a high status in keeping with eastern Islamic trends.

The spread of tin-glaze technology on a regional level is associated with the collapse of the Caliphate of Córdoba (late tenth-early eleventh centuries). Polychrome tin-glazed ware ceased to be an exclusive production of the Umayyad capital, as new workshops were established in other urban centres, the new capitals of the Taifa kingdoms (e.g. Sevilla, Málaga, Denia, Zaragoza). During the civil war, most of the city of Córdoba was abandoned - including the ceramic workshops - and the populated area was reduced to the walled city. Simultaneously, a diaspora of specialised potters spread tin-glaze knowhow throughout al-Andalus.

\section{Looking east}

Another important point has been to clarify the possible technological transfers from other Islamic lands. Comparing the eastern Mediterranean and North African technological glaze traditions with that of Iberia, we can see notable differences. Alkali glazes and slips were never used and underglaze decorations were not applied, at least by the Córdoba artisans. Nevertheless, the use of glazes with a high lead content and the application of decorations over a white opaque background are also found on some of the Abbasid productions. However, the local potters did not copy imported glazed ware, since there are also evident differences in terms of vessel shapes (the lack of a foot on the dishes) and decorative patterns (the predominance of plant motifs, simple designs, etc.).

The situation seems different for the lustre technology. Lustre began in the Abbasid caliphate, but its expansion to other regions was particularly slow and progressive. The peculiarities and difficulties of lustre technology have always been considered responsible for its slow spread. Lustre did not reach the Iberian Islamic kingdoms until the eleventh century and its origin (directly from the Fatimid Caliphate or through North Africa-Tunisia) is still a matter of debate and further study. What is clear is that Spanish lustre ware copied technology, decorations and shapes.

Another aim has been to identify some of the networks and commercial flows between the eastern Mediterranean regions and al-Andalus based on the ceramics trade. The small percentage of glazed imports documented from other Islamic centres during the ninth and tenth centuries rules out the possibility of an organised, large-scale trade in glazed ceramics in the western Mediterranean during the early medieval period, unlike between Mesopotamia and China or Japan (Priestman 2016). It is more likely that glazed ceramics travelled individually along with people (e.g. on pilgrimages, as diplomatic gifts, etc.) or with other trading goods (e.g. silk fabrics), rather than as a main trading product. However, according to the archaeological evidence on the Iberian Peninsula (e.g. Denia or Mértola), foreign glazed ceramics became more common in al-Andalus from the eleventh century, a period that coincides with Fatimid control of the Mediterranean routes.

Furthermore, the technology of the glazed imports studied was not copied by local potters and their shapes and decorations had little influence on the al-Andalus productions. It suggests that the knowledge of medieval glaze techniques was transferred directly by potters, who migrated and established new workshops, and not by treaties. Shapes and especially decorations appear to have been adapted to the local tastes.

\section{Conclusion}

A progressive introduction of glaze technology through three technological waves has been revealed. However, they arrived with some delay with respect to the eastern Islamic regions. The few items of imported glazed ware found coming from other contemporary production centres do not seem to have influenced, at least not immediately, the local glaze productions.

Al-Andalus developed its own glaze technology during the ninth and tenth centuries. This is indicated by the use of high-lead-content and not alkali-based transparent glazes and distinctive vessel shapes and decorative patterns compared to other contemporary glaze productions. Moreover, the colour decorations were applied as overglaze for both the polychrome transparent lead-glazed and opaque tin-glazed wares. This fact rules out, at least in the beginning, the traditionally proposed link with the polychrome transparent lead-glazed ware 
produced in Ifriqiya (Tunisia), which was characterised by lead-alkaline glazes and underglaze painted decoration.

When the first technological wave reached Iberia, all the glaze technologies were known in the eastern Islamic world. However, it took another two centuries for the other two waves to arrive. This slow transmission can be explained by the fact that the techniques could only be transmitted through specialised potters travelling to new territories. All the raw materials needed for manufacturing the glaze technologies studied in this paper were available in Iberia, so it was not a problem of supply. At a time when this technology was not yet widespread, specialised potters migrated or were attracted to centres of wealth and power, where potential markets could provide a demand for their products. Hence, in the case of the Iberian Peninsula, they were installed both in seats of power and in sea ports. Thus, the reasons seem more economic than political, although it is true that the Córdoba caliphal tin-glazed ware was used as a means of political propaganda and Seville lustre ware was decorated with the name of the Abbadid king.

Regarding the distribution of early glazed ware from the al-Andalus workshops, there was a limited regional dissemination, as the majority of the production was destined for local consumption. The glazed ware market was concentrated in the south of Iberia during the ninth and tenth centuries. The scarcity of glazed ware finds in the western (present-day Portugal) and northern areas coincides with less Islamised areas (understanding Islamisation as a subsequent transformation of social practices) (Carvajal 2013). This could be related to the absence of a previous market for sophisticated tableware (even unglazed ware) that continued at least into the tenth century and the slow adoption of new habits and trends.

It is still largely unknown what happened in the rest of the central and western Mediterranean regarding the transmission of glaze technology and whether similar patterns were developed in other regions. What does seem clear is that the dissemination of medieval glaze technology was also slow in other western Mediterranean regions. In fact, if we look at Christian Europe (excluding the Byzantine area, which had a different tradition and evolution), glaze technology was incorporated later, from the twelfth century. Consequently, the study of the early glaze technological transfers in al-Andalus can contribute to a better understanding of how medieval technological transmissions took place in a broader context.

\section{Acknowledgements}

This project has received funding from the European Union's Horizon 2020 Research and Innovation Programme, Marie Sklodowska-Curie Action (H2020MSCA-IF-2015, Grant N 702019).

\section{References}

Ben Amara, A., SchvoereR, M., Daoulatli, A. and Rammah, M. 2001. 'Jaune de Raqqada' et autres couleurs de céramiques glaçurées aghlabides de Tunisie (IX - X siècles). Revue d'Archéométrie 25(1): 179-186.

Carvajal, J.C. 2013. Islamicization or Islamicizations? Expansion of Islam and social practice in the Vega of Granada (south-east Spain). World Archaeology 45(1): 109-123.

Castillo, F. and Martínez, R. 1993. Producciones cerámicas en Bayyana, I Encuentro de Arqueología y Patrimonio, La cerámica altomedieval en el sur de al-Andalus. Salobreña, 1990. Granada: 67-116.

Escudero, J. 1991. La cerámica decorada en "verde y manganeso" de Madinat al-Zahra. Cuadernos de Madīnat al-Zahrā 2: 127-161.

Gómez, S. et al. (in press). El uso del vidriado en el Garb al-Andalus y su lenta difusión, Vidriados medievales en España. Investigaciones recientes.
Heidenreich, A. 2007. La loza dorada medieval en la Península Ibérica. Aportaciones recientes a su evolución y nuevos datos para su cronología. Anales de Arqueología Cordobesa 18: 401-424.

Íñiguez, $\mathrm{M}^{\mathrm{a} C}$ and Mayorga, J.F. 1993. Un alfar emiral en Málaga, I Encuentro de Arqueología y Patrimonio. La cerámica altomedieval en el sur de al-Andalus. Granada: 117-138.

Matin, M., Tite, M. and Watson, P. 2018. On the origins of tin-opacified ceramic glazes: New evidence from early Islamic Egypt, the Levant, Mesopotamia, Iran, and Central Asia. Journal of Archaeological Science 92: 42-66.

Molera, J., Carvajal, J.C., Molina, G. and Pradell, T. 2018. Glazes, colourants and decorations in early Islamic glazed ceramics from the Vega of Granada (9th to 12th centuries AD). Journal of Archaeological Science: Reports 21: 1141-1151.

Ortega, J.M., Gutiérrez, F.J., Pérez-Arantegui, J. and Déléry, C. 2013. La cerámica dorada en el noreste 
de la Península Ibérica: las taifas de Zaragoza y Albarracín. Proceedings of REMAI: 291-324.

Peña, R., García, V. and Zarco, E. (in press). Crisoles para la elaboración de vidrio de época visigoda localizados en la Vega Baja de Toledo, Vidriados medievales en España. Investigaciones recientes.

Pradell, T., Molera Smith, A., Climent-Font, A. and Tite, M. 2008. Technology of Islamic lustre. Journal of Cultural Heritage 9: 123-128.

Priestman, S. 2016. The silk road or the sea? Journal of Islamic Archaeology 3(1): 1-36.

Rosselló, G. 1995. La céramique verte et brune en al-Andalus du Xe au XIIIe siècle, Le Vert et le
Brun: de Kairouan à Avignon, céramiques du Xe au XVe siècle, Marseille: 104-117.

Salinas, E. and Pradell, T. 2018. The transition from lead transparent to tin-opacified productions in the western Islamic lands: al-Andalus, c. 875-929 CE. Journal of Archaeological Science 94: 1-11.

Salinas, E. and Zozaya, J. 2016. Pechina: el antecedente de las cerámicas vidriadas islámicas en al-Andalus, $\mathrm{X}$ Congresso Internacional Cerâmica Medieval no Mediterrâneo. Silves-Mértola: 573-576.

Watson, O. 2004. Ceramics from Islamic Lands. London: Thames \& Hudson. 